\title{
Stylet elemental signatures indicate population structure in a holobenthic octopus species, Octopus pallidus
}

\author{
Zoë A. Doubleday ${ }^{1, *}$, Gretta T. Pecl ${ }^{1}$, Jayson M. Semmens ${ }^{1}$, Leonid Danyushevsky ${ }^{2}$ \\ ${ }^{1}$ Marine Research Laboratories, Tasmanian Aquaculture \& Fisheries Institute, University of Tasmania, Private Bag 49, \\ Hobart, Tasmania 7001, Australia \\ ${ }^{2}$ Centre for Ore Deposit Research, University of Tasmania, Private Bag 79, Hobart, Tasmania 7001, Australia
}

\begin{abstract}
Targeted trace elemental analysis was used to investigate the population structure and dispersal patterns of the holobenthic octopus species Octopus pallidus (Hoyle, 1885). Multi-elemental signatures within the pre-hatch region of the stylet (an internal 'shell') were used to determine the common origins and levels of connectivity of individuals collected from 5 locations in Tasmania. To determine whether hatchling elemental signatures could be used as tags for natal origin, hatchling stylets from 3 of the 5 locations were also analysed. We analyzed 12 elements using laser ablation inductively-coupled plasma-mass spectrometry (LAICPMS). Of the 12 elements, 7 were excellent spatial discriminators. There was evidence of high-level structuring with distinct groupings between all sites (the 2 closest being $85 \mathrm{~km}$ apart) within the adult $O$. pallidus population, suggesting that all adults had hatched in or near their respective collection sites. The hatchling signatures showed significant spatial variation, and a high percentage of individuals could successfully be traced back to their collection locations. However, they could not be used to trace adults back to their natal site, due to significant differences in element concentrations in hatchling and adult stylets, which was likely the result of differences in Ca concentration. This study presents the first insights into the population structure of a holobenthic octopus species using stylet elemental signatures, which will have important implications for the sustainable management of $O$. pallidus.
\end{abstract}

KEY WORDS: Population structure $\cdot$ Octopus $\cdot$ Stylet elemental signatures $\cdot$ Laser ablation

Resale or republication not permitted without written consent of the publisher

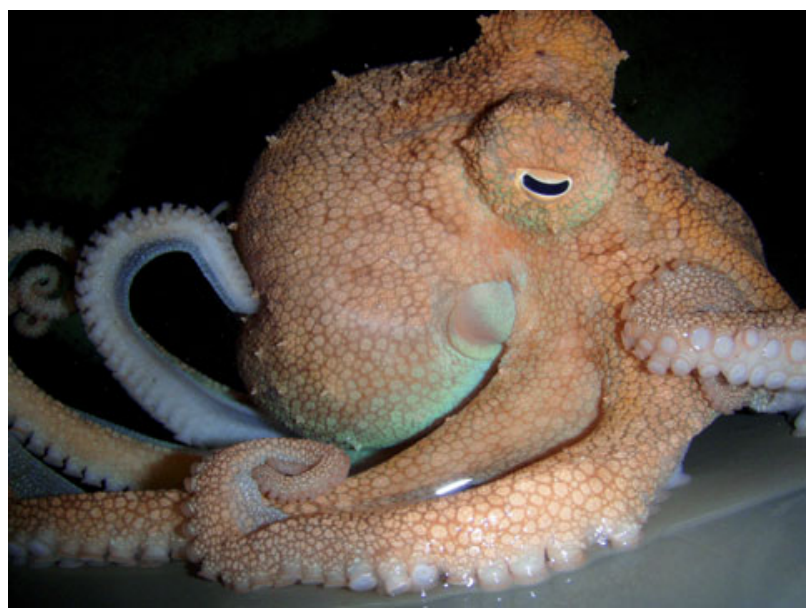

Octopus pallidus, a holobenthic species found in south-east Australia

Photo: Stephen Leporati

\section{INTRODUCTION}

Population structure and connectivity determine the spatial scale at which localised populations operate. They may be predominantly self-recruiting, depend on some exchange from neighbouring populations, or freely interbreed across the distributional range of the species (Fowler et al. 2005). These parameters of marine populations, therefore, are key properties for determining the resilience of populations to harvesting, and for the development of effective conservation and fisheries management strategies (Thorrold et al. 2001, Gillanders 2002). However, reconstructing the 
dispersal patterns of marine species throughout their life history cycle, particularly the early stages, has proved to be a continuing challenge (Jones et al. 2005, Bradbury et al. 2008). Traditional tag-recapture methods are often inadequate due to the small size, large number and high mortality rates of offspring (Gillanders 2005, Warner et al. 2005). Genetic markers can be valuable for investigating levels of connectivity relevant to long-term intergenerational population changes (e.g. Shaw et al. 1999, Kassahn et al. 2003, Buresch et al. 2006); however, only a very low exchange rate is required to maintain genetic homogeneity (Carvalho \& Hauser 1994).

A more direct approach to the measurement of dispersal employs the analysis of natural elemental signatures within the hard bio-mineralised structures of marine organisms, which can be influenced by the local physical and biological availability of various elements in the seawater. Elemental signatures have the advantage that all individuals within a population are 'tagged', regardless of size (Semmens et al. 2007), and as they reflect the present movement patterns of a population, they may reveal distinct sub-populations that are otherwise genetically homogenous due to low-level mixing (Campana \& Thorrold 2001, Arkhipkin et al. 2004). The development of targeted microprobe techniques, such as laser ablation inductivelycoupled plasma-mass spectrometry (LA-ICPMS), has enabled the selective elemental analysis of specific, temporally related regions within structures such as fish otoliths (Campana 1999), gastropod shells (Zacherl 2005), bivalve shells (Becker et al. 2005) and squid statoliths (Zumholz et al. 2007). Furthermore, elemental signatures from the pre-hatch region of an adult structure have been matched with signatures from equivalent juvenile structures, allowing the natal origins of adults and dispersal trajectories of juveniles to be determined (e.g. Forrester \& Swearer 2002, Hamer et al. 2005).

In spite of the ecological and increasing commercial significance of cephalopods, the population structure and dispersal patterns of most species are poorly understood. For octopus, such studies are predominantly restricted to Octopus vulgaris, a merobenthic species with a planktonic larval stage, and are largely based on genetics (e.g. Maltagliati et al. 2002, Oosthuizen et al. 2004). Octopus pallidus (Hoyle, 1885) is a small species that growths up to a weight of $1 \mathrm{~kg}$ and which is found in coastal southeast Australian waters (Stranks 1996). The species is holobenthic and produces large, well-developed benthic hatchlings that adopt an adult lifestyle immediately after hatching. $O$. pallidus is currently harvested throughout Bass Strait, Tasmania, with a current annual catch of 80 to $90 \mathrm{t}$ (Ziegler et al. 2007). No population-level research is conducted on holobenthic octopus species, which also constitute other, much larger fisheries, including the Octopus maya fishery in Mexico (Arreguín-Sánchez et al. 2000) and Eledone cirrhosa fishery in the Mediterranean (Orsi Relini et al. 2006).

There are no published studies on the targeted elemental analysis of both juvenile and adult cephalopod hard structures. However, targeted elemental analysis has been applied successfully to adult stylets of a merobenthic octopus species (Doubleday et al. 2008). Stylets are a pair of fine, cartilage-like rods embedded within the mantle musculature. They are a little known structure unique to Octopoda and are thought to represent a remnant shell (Bizikov 2004). Unlike octopus statoliths, which lack concentric growth and agerelated increments (Jackson 1994), stylets have distinct concentric regions, a visible pre-hatch region, and daily growth increments (Doubleday et al. 2006).

This study utilises targeted elemental analysis of both hatchling and adult stylets to examine the population structure of the holobenthic octopus species Octopus pallidus. More specifically, we determine whether (1) elemental signatures from the pre-hatch region of adult stylets can be used to examine population structure and dispersal patterns, (2) hatchling elemental signatures exhibit sufficient spatial variation to act as tags for natal origin, (3) hatchling signatures are stable over short time periods, and (4) adult signatures can be matched back to the hatchling signatures and thus used to determine the natal origins of the adults.

\section{MATERIALS AND METHODS}

Collection of specimens. Octopus hatchlings were collected from 3 sites: Circular Head $(\mathrm{CH})$ on the north coast of Tasmania, and Mercury Passage (MP) and Northwest Bay (NWB) on the southeast coast of Tasmania, Australia (Table 1, Fig. 1). Unbaited octopus pots attached to demersal longlines and set at depths between 12 to $30 \mathrm{~m}$ were used to provide nesting habitat for mature females. Pots were deployed for 3 to 5 mo and were checked regularly for egg broods. If eggs were present, a PVC mesh bag was tied securely around the pot to aid hatchling collection and prevent predation on the eggs. The pot was subsequently checked every 2 to $4 \mathrm{wk}$. This procedure did not affect the mother, as she did not feed or leave her 'den' during egg development. The well developed benthic hatchlings were collected as 'near hatching' eggs or recently hatched individuals. To assess the temporal short-term variation in hatchling elemental signatures, 2 additional batches of hatchlings were collected from NWB (Table 1), with collections spaced 4 to 6 wk apart. All specimens were frozen (the $-18^{\circ} \mathrm{C}$ ) upon collection. 
Table 1. Octopus pallidus. Details of sample collection. Adults were collected on several days within the time period given. n.c.: no specimens collected

\begin{tabular}{|lcccc|}
\hline Sample site & $\begin{array}{c}\text { Collection date } \\
\text { (hatchlings) }\end{array}$ & $\begin{array}{c}\text { No. of } \\
\text { hatchlings }\end{array}$ & $\begin{array}{c}\text { Collection date } \\
\text { (adults) }\end{array}$ & $\begin{array}{c}\text { No. of } \\
\text { adults }\end{array}$ \\
\hline West Flinders Island (WFI) & n.c. & 0 & June 2006 & 17 \\
East Flinders Island (EFI) & n.c. & 0 & April 2007 & 19 \\
Northwest Bay (NWB) & & & & \\
Collection 1 & 15 Nov 06 & 40 & May - Sept 2007 & 8 \\
Collection 2 & 14 Dec 06 & 33 & & \\
Collection 3 & 1 Feb 07 & 36 & & 19 \\
Mercury Passage (MP) & 30 June 2006 & 72 & Feb - April 2007 & 19 \\
Circular Head (CH) & 2 May 2006 & 32 & November 2006 & 28 \\
\hline
\end{tabular}

mature) were assigned according to ovary size and level of egg development, and Stage 5 was assigned to postspawning females (Leporati et al. 2008). Octopuses ranged in weight from 280 to $1012 \mathrm{~g}$, all males were mature and most females were either Stage 3 or 4 .

Stylet preparation. Hatchling stylets were carefully removed from partially thawed animals under a dissecting microscope. Stylets were placed on glass Petri dishes and oven-dried overnight at $60^{\circ} \mathrm{C}$. Once dried, the main bulk of tissue was scraped away from the

Using pots and longlines, adult octopuses were collected 6 to 10 mo after the hatchlings from the same sites described above. According to an age study of Octopus pallidus from the collection site, mature adults had an average age of 8 mo (Leporati et al. 2008). Therefore, it is likely that these adults hatched around the time the hatchlings were collected. To minimise potentially confounding temporal variation in elemental signatures, it is recommended that adults are assigned to natal site based on juvenile elemental signatures that are from a similar age cohort to the adults (Gillanders 2002, 2005). Adults without an 'equivalent' hatchling sample were additionally collected from west Flinders Island (WFI) and east Flinders Island (EFI) (Table 1, Fig. 1). For each adult specimen, whole weight $(\mathrm{g})$, sex and maturity stage were recorded. Males were classified as mature or immature, depending on the presence or absence of visible spermatophores in Needham's sac. Females were assigned a maturity stage from 1 to 5 . Stages 1 to 4 (immature to

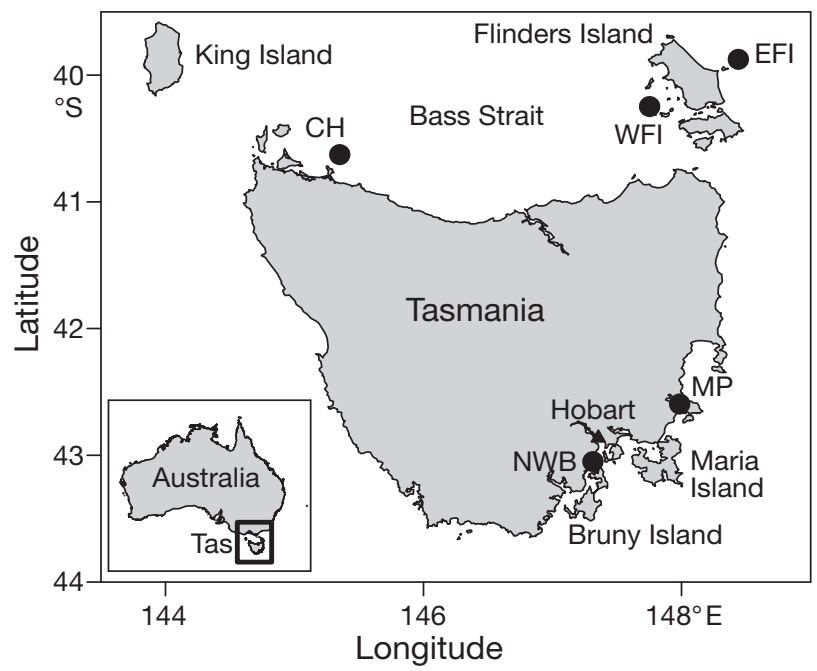

Fig. 1. Location of sites $(\bullet)$ for sampling Octopus pallidus. $\mathrm{CH}$ : Circular Head; WFI: west Flinders Island; EFI: east Flinders Island; MP: Mercury Passage; NWB: Northwest Bay stylets, and about 20 stylets were then placed flat onto double-sided tape stuck onto glass plates. Epoxy resin was poured into $25 \mathrm{~mm}$ moulds placed on the tape and then oven-dried for $3 \mathrm{~h}$ at $60^{\circ} \mathrm{C}$. The mounts were not polished, as this turned out to immediately remove the stylet from the epoxy. Using a light microscope, individual photos were taken of each mounted stylet to aid in the detection of the stylet material once in the ablation chamber. Adult stylets were removed from mantle tissue (see Bizikov 2004 for stylet location) and processed according to the methods outlined in Doubleday et al. (2008). All animals were fresh, except for $50 \%$ of the EFI individuals and all of the WFI individuals, which were frozen prior to dissection.

Analytical methods. Elemental analyses were performed using LA-ICPMS at the Centre for Ore Deposit Research (CODES), University of Tasmania. For more details on the laser ablation system, analytical specifications, detection limits (DLs) and external and internal standards used, refer to Doubleday et al. (2008). For the adults, the pre-hatch region visible within the stylet cross section was targeted (see Doubleday et al. 2006) and ablation spot size was $35 \mu \mathrm{m}$ (which is the approximate size of the pre-hatch region) with a laser pulse rate of $10 \mathrm{~Hz}$. To remove surface contamination, each sample was pre-ablated at $1 \mathrm{~Hz}$ for $5 \mathrm{~s}$ prior to analysis. For the hatchlings, the laser was targeted closest to the 'bend' region of the stylet (see Doubleday et al. 2006) where possible, to achieve maximum ablation yield. The presence of $\mathrm{Ca}$ in the analysis was used to distinguish the surrounding tissue from the stylet and to determine the position of the integration interval (Fig. 2). Samples with integration intervals of $\leq 2 \mathrm{~s}$ were discarded. Hatchling ablation spot size was $20 \mu \mathrm{m}$ with a laser pulse rate of 5 to $10 \mathrm{~Hz}$. Pre-ablation was not performed on the hatchling stylets; however, surface contamination spikes were not included in the integration interval, as the laser was ablating through epoxy and tissue in the first few seconds (Fig. 2). The following suite of 12 elements was recorded during 


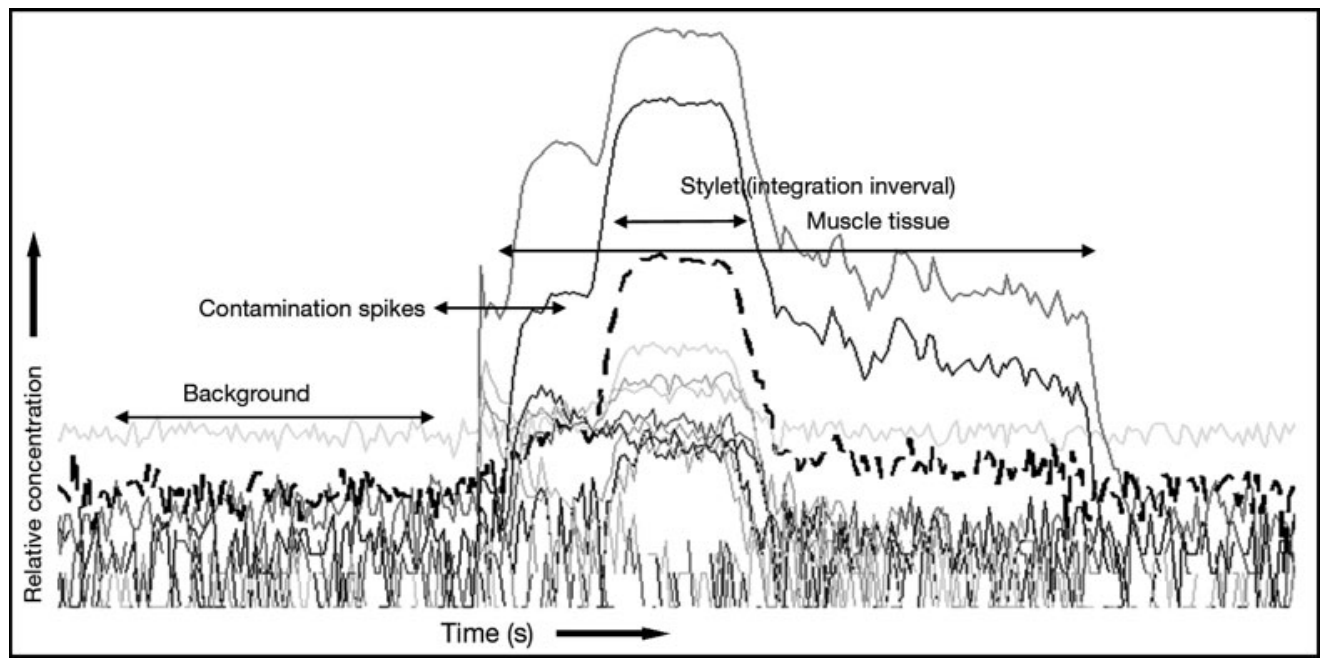

Fig 2. Octopus pallidus. Example of raw data from laser ablation analysis of a hatchling stylet. - - - - : Ca concentration; other lines represent different elements. An increase in Ca concentration (the internal standard) as shown indicates the ablation of stylet material, and allows for correct selection of the integration interval

each analysis for both adults and hatchlings: ${ }^{7} \mathrm{Li},{ }^{24} \mathrm{Mg}$, ${ }^{55} \mathrm{Mn},{ }^{59} \mathrm{Co},{ }^{60} \mathrm{Ni},{ }^{65} \mathrm{Cu},{ }^{208} \mathrm{~Pb},{ }^{66} \mathrm{Zn},{ }^{75} \mathrm{As},{ }^{85} \mathrm{Rb},{ }^{88} \mathrm{Sr}$ and ${ }^{137} \mathrm{Ba}$. Co and Ni were below DLs in a large proportion of the hatchling samples and were therefore excluded from further analysis. $\mathrm{Co}, \mathrm{Ni}, \mathrm{As}$ and $\mathrm{Pb}$ were below DLs in a small number of adult samples. One method of treating values generated by an element falling below DLs is to substitute them with a constant, such as 0.5 times the DL (Farnham et al. 2002). Statistical analyses on the adult stylets were performed using both the original values and substituted values based on 0.5 times the $\mathrm{DL}(\mathrm{Pb}=0.008, \mathrm{Co}=0.006, \mathrm{Ni}=0.032$, and As $=0.081$ ); however, the results were the same (the latter are presented).

Statistical analyses. To determine differences in adult elemental signatures among sites, analysis of variance (ANOVA) and multivariate analyses were performed. To meet ANOVA assumptions, all elements were $\log _{10}$ transformed. All a posteriori comparisons among sites were conducted using Tukey's honestly significant difference (HSD) test. All elements, except $\mathrm{Ni}$, showed significant univariate differences and were included in the multivariate analyses $(n=11)$. Forward step-wise discriminant function analysis (DFA) showed that $\mathrm{Zn}, \mathrm{Sr}, \mathrm{Ba}$ and $\mathrm{Cu}$ did not contribute to the discrimination between sites. To reduce the number of dependent variables, a second DFA was performed with these elements removed. Differences in multi-elemental signatures $(n=7)$ among sites were determined using multivariate analysis of variance (MANOVA) and visualised using canonical discriminant plots. To assess how accurately adults could be assigned to their site of origin using multi-element signatures, cross-validation classifications were performed using jack-knife procedures. To test for sex and site and differences between sexes, a separate 2-way ANOVA was performed for each element using all individuals $(n=91)$. Regression analysis was used to examine the relationship between age and element concentration using individuals from $\mathrm{CH}(\mathrm{n}=28)$. Age data for the $\mathrm{CH}$ individuals was derived from a separate study (Leporati et al. 2008). To determine whether hatchling elemental signatures were useful tags for natal origin, a series of univariate and multivariate analyses were performed using the same procedure described above for the adults. Again, $\mathrm{Sr}, \mathrm{Mn}$ and $\mathrm{Zn}$ were excluded from the second DFA, leaving a total of 7 elements.

To assess the extent of short-term variation within hatchling elemental signatures, a DFA and MANOVA were performed on the 3 hatchling collections from NWB using all detected elements $(n=10)$. A second canonical analysis and cross-validation on the hatchling spatial data, including pooled data for all NWB collections, was also performed. To determine whether the adults, collected 6 to 8 mo later, matched the agecohort of the hatchlings (as a mismatch of cohorts may have introduced temporal bias), age data for the $\mathrm{CH}$ individuals was analysed.

\section{RESULTS}

\section{Adult signatures}

All single-element signatures, except for $\mathrm{Ni}$, significantly differed among sites (ANOVA: $p<0.05$ ) (Table 2). The 11 elements excluding Ni were significantly different between EFI and MP; in contrast, EFI and WFI were only separated by differences in $\mathrm{Mn}, \mathrm{Sr}$, and $\mathrm{Cu}$ (Table 3). Major differences for individual elements among sites included high levels of As at EFI and WFI, $\mathrm{Co}$ at $\mathrm{CH}$, exceptionally high levels of $\mathrm{Pb}$ in NWB, and low levels of Mn at WFI and NWB. The multi-element signature was also highly significant among sites (MANOVA, Pillai's trace $=2.87, F_{28,332}=$ 30.6, $\mathrm{p}<0.001$ ). All elements, except $\mathrm{Zn}, \mathrm{Sr}, \mathrm{Ba}$ and $\mathrm{Cu}$, 
Table 2. ANOVA comparing single-element adult Octopus pallidus signatures among sites. Degrees of freedom (df): site $=4$; error $=86$ for each element

\begin{tabular}{|c|c|c|c|}
\hline Element & MS & $F$ & $\mathrm{p}$ \\
\hline $\mathrm{Li}$ & $\begin{array}{l}0.41 \\
0.01\end{array}$ & 56.24 & 0.000 \\
\hline $\mathrm{Ba}$ & $\begin{array}{l}0.02 \\
0.01\end{array}$ & 4.44 & 0.003 \\
\hline $\mathrm{Sr}$ & $\begin{array}{l}162941 \\
16321\end{array}$ & 9.98 & 0.000 \\
\hline $\mathrm{Cu}$ & $\begin{array}{l}0.42 \\
0.07\end{array}$ & 5.41 & 0.000 \\
\hline $\mathrm{Zn}$ & $\begin{array}{l}0.04 \\
0.02\end{array}$ & 3.12 & 0.017 \\
\hline $\mathrm{Rb}$ & $\begin{array}{l}0.85 \\
0.01\end{array}$ & 56.24 & 0.000 \\
\hline $\mathrm{Mg}$ & $\begin{array}{l}0.03 \\
0.00\end{array}$ & 88.00 & 0.000 \\
\hline $\mathrm{Mn}$ & $\begin{array}{l}1.60 \\
0.04\end{array}$ & 47.08 & 0.000 \\
\hline As & $\begin{array}{l}8.19 \\
0.08\end{array}$ & 87.35 & 0.000 \\
\hline $\mathrm{Ni}$ & $\begin{array}{l}0.16 \\
0.09\end{array}$ & 1.81 & 0.132 \\
\hline $\mathrm{Pb}$ & $\begin{array}{l}6.44 \\
0.09\end{array}$ & 62.49 & 0.000 \\
\hline Co & $\begin{array}{l}0.84 \\
0.07\end{array}$ & 10.30 & 0.000 \\
\hline
\end{tabular}

significantly contributed to the discrimination between sites (DFA: $\mathrm{p}<0.05)$, with DF 1 and 2 describing 50 and $27 \%$ of the variation, respectively. Mg contributed most to the variation among sites, followed by As and $\mathrm{Pb}$, while Li and Co contributed the least (Table 4). The canonical plot showed a clear separation between $\mathrm{CH}$, MP and NWB, mainly due to differences in $\mathrm{Mg}, \mathrm{Rb}$ and Mn, with MP appearing to have the most variable signature (Fig. 3). EFI and WFI had relatively similar signatures and were separated from the other sites
Table 4. Standardised canonical coefficients from adult Octopus pallidus data for discriminant functions (DF) 1 and 2 for each element entered in the final discriminant function analysis. Coefficients represent the relative contribution of each element to each DF

\begin{tabular}{|lrr|}
\hline Element & DF1 & DF2 \\
\hline $\mathrm{Mg}$ & -0.76 & 0.51 \\
$\mathrm{~Pb}$ & -0.32 & -0.23 \\
$\mathrm{Mn}$ & -0.11 & -0.75 \\
$\mathrm{As}$ & 0.81 & -0.10 \\
$\mathrm{Rb}$ & -0.03 & 0.63 \\
$\mathrm{Li}$ & 0.13 & 0.11 \\
$\mathrm{Co}$ & -0.03 & -0.28 \\
\hline
\end{tabular}

largely by differences in As and Mg. Based on the 7 elements entered in the final DFA, the overall crossvalidation rate was very high $(98.9 \%)$, with only one individual from WFI incorrectly assigned to EFI (Table 5). The 2 different pre-dissection treatments (frozen versus fresh animals) had a minimal effect on the spatial analyses, with $100 \%$ of the EFI individuals correctly traced back to their collection site (even though $50 \%$ were frozen), and with only 2 elements differing significantly at WFI (100\% frozen) and all other sites. There was no relationship between age and element concentration $\left(\mathrm{r}^{2}<0.1\right)$, and no significant effect of sex on elemental concentration was found for any element (2-way ANOVA. p > 0.05).

\section{Hatchling signatures}

All single stylet element signatures, except $\mathrm{Sr}$, were significantly different among sites (ANOVA, p < 0.05) (Table 6). All elements, except Ba, differed between

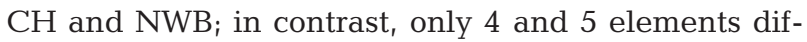
fered between $\mathrm{CH}$ and $\mathrm{MP}$, and between MP and NWB, respectively (Table 7). Elemental concentrations

Table 3. Octopus pallidus. Concentration (conc.) of elements (ppm, mean $\pm \mathrm{SD}$ ) in pre-hatch region of adult stylets for each of the 5 sites. AP: mean analytical precision $(\mathrm{ppm}) ;$ T: Tukeys HSD, significant differences $(\mathrm{p}<0.05)$ indicated by letters $(\mathrm{A}, \mathrm{B}, \mathrm{C})$. For abbreviations, see Table 1

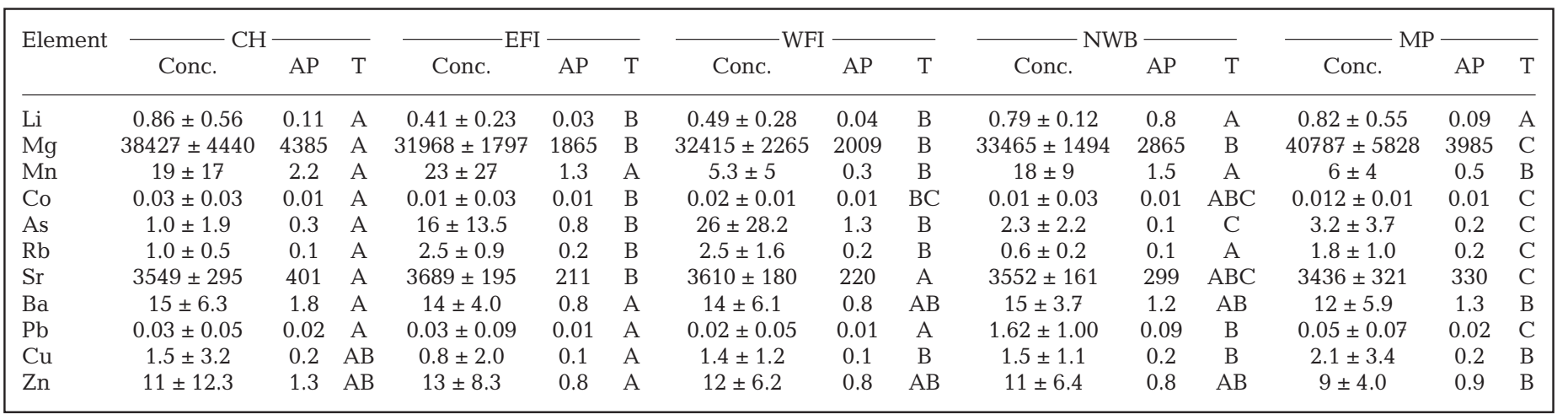


Table 5. Predicted group memberships from cross-validation classification procedures for each site, based on discriminatin function analysis scores from adult Octopus pallidus data. Results are given as percentage of the total number of individuals traced back to each site; bold values indicate correct classifications. For site abbreviations, see Table 1

\begin{tabular}{|lccccc|}
\hline Site & CH & WFI & EFI & NWB & MP \\
\hline CH & $\mathbf{1 0 0}$ & 0 & 0 & 0 & 0 \\
WFI & 0 & $\mathbf{9 4 . 7}$ & 5.3 & 0 & 0 \\
EFI & 0 & 0 & $\mathbf{1 0 0}$ & 0 & 0 \\
NWB & 0 & 0 & 0 & $\mathbf{1 0 0}$ & 0 \\
MP & 0 & 0 & 0 & 0 & $\mathbf{1 0 0}$ \\
\hline
\end{tabular}

Table 6. ANOVA comparing single-element Octopus pallidus hatchling signatures among sites. Degrees of freedom (df): site $=2$; error $=44$ for each element

\begin{tabular}{|c|c|c|c|}
\hline Element & MS & $F$ & $\mathrm{p}$ \\
\hline $\mathrm{Li}$ & $\begin{array}{l}0.41 \\
0.02\end{array}$ & 21.04 & 0.000 \\
\hline $\mathrm{Ba}$ & $\begin{array}{l}1.04 \\
0.05\end{array}$ & 21.39 & 0.000 \\
\hline $\mathrm{Sr}$ & $\begin{array}{l}0.00 \\
0.00\end{array}$ & 0.8 & 0.436 \\
\hline $\mathrm{Cu}$ & $\begin{array}{l}1.42 \\
0.10\end{array}$ & 12.66 & 0.000 \\
\hline $\mathrm{Zn}$ & $\begin{array}{l}0.60 \\
0.04\end{array}$ & 11.56 & 0.000 \\
\hline $\mathrm{Rb}$ & $\begin{array}{l}0.94 \\
0.05\end{array}$ & 17.26 & 0.000 \\
\hline $\mathrm{Mg}$ & $\begin{array}{l}0.25 \\
0.01\end{array}$ & 16.54 & 0.000 \\
\hline $\mathrm{Mn}$ & $\begin{array}{l}0.07 \\
0.01\end{array}$ & 5.72 & 0.005 \\
\hline As & $\begin{array}{l}0.96 \\
0.08\end{array}$ & 12.73 & 0.000 \\
\hline $\mathrm{Pb}$ & $\begin{array}{l}2.17 \\
0.06\end{array}$ & 29.61 & 0.000 \\
\hline
\end{tabular}

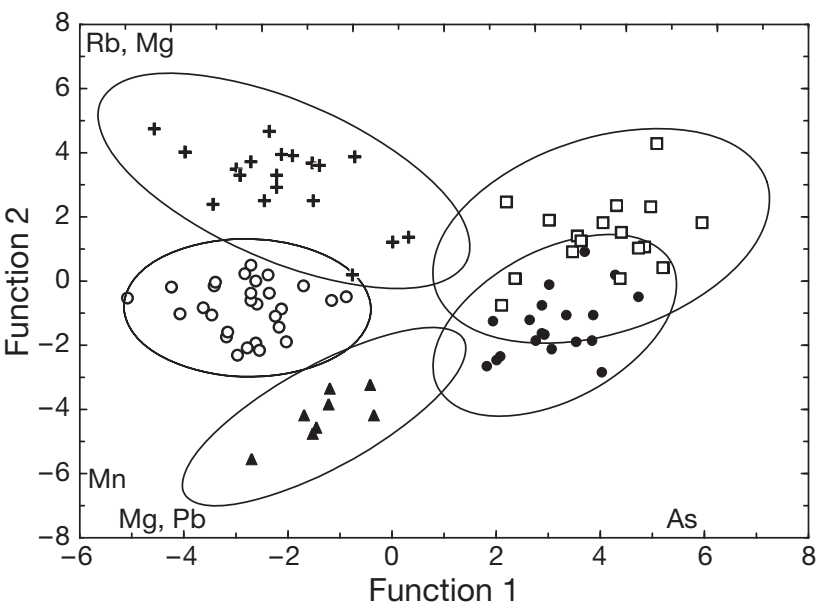

Fig. 3. Canonical discriminant plots comparing multi-element signatures of Octopus pallidus adults among sites. Elements contributing most variation to the data (canonical coefficients) are indicated at both ends of each axis. Ellipses represent $95 \%$ confidence intervals around the centroids of each group. ०: Circular Head; •: east Flinders Island; $\square$ : west Flinders Island; $\mathbf{\Delta}$ : Northwest Bay; +: Mercury Passage

in hatchlings were several magnitudes higher than adult concentrations, with only 2 elements $(\mathrm{Mg}$ and $\mathrm{Mn}$ ) sharing a relative concentration pattern similar to that of any adult signatures from $\mathrm{CH}, \mathrm{NWB}$ and MP (see Tables $3 \&$ 7). Multi-elemental signature was also significantly different among sites (MANOVA, Pillai's trace $\left.=1.56, F_{14,78}=20.45, \mathrm{p}<0.001\right)$. All elements, except $\mathrm{Zn}$ and $\mathrm{Mn}$, contributed significantly to the discrimination between sites (DFA, $p<0.05$ ), with discriminant functions (DF) 1 and 2 describing 78 and $22 \%$ of the variation, respectively. The canonical coefficients indicated that, overall, $\mathrm{Rb}, \mathrm{Cu}$ and $\mathrm{Mg}$ were major contributors to the variation among sites (Table 8). The canonical plot showed a distinct separation between the 3 sites, with $\mathrm{CH}$ and MP separated from NWB largely by differences in $\mathrm{Rb}, \mathrm{Mg}$ and $\mathrm{Cu}$,

Table 7. Octopus pallidus. Concentration of elements (ppm, mean \pm SD) in hatchlings for each of 3 sites. AP: mean analytical precision $(\mathrm{ppm})$; T: results from Tukeys HSD, significant differences $(\mathrm{p}<0.05)$ indicated by letters $(\mathrm{A}, \mathrm{B})$. For site abbreviations, see Table 1; n: number of successful ablations; t: average integration interval (s)

\begin{tabular}{|c|c|c|c|c|c|c|c|c|c|}
\hline \multirow[t]{2}{*}{ Element } & \multicolumn{3}{|c|}{$\mathrm{CH}(\mathrm{n}=11 ; \mathrm{t}=6.3)$} & \multicolumn{3}{|c|}{$\mathrm{MP}(\mathrm{n}=9 ; \mathrm{t}=3.8)$} & \multicolumn{3}{|c|}{$\operatorname{NWB}(\mathrm{n}=27 ; \mathrm{t}=7.2)$} \\
\hline & Conc. & $\mathrm{AP}$ & $\mathrm{T}$ & Conc. & $\mathrm{AP}$ & $\mathrm{T}$ & Conc. & $\mathrm{AP}$ & $\mathrm{T}$ \\
\hline $\mathrm{Li}$ & $19 \pm 18$ & 7.7 & $\mathrm{~B}$ & $13 \pm 7.5$ & 3.5 & B & $7 \pm 3.4$ & 2.0 & $\mathrm{~A}$ \\
\hline $\mathrm{Mg}$ & $133023 \pm 19544$ & 110380 & B & $133348 \pm 71886$ & 25082 & B & $78869 \pm 31878$ & 8621 & A \\
\hline $\mathrm{Mn}$ & $86 \pm 40$ & 25 & A & $63 \pm 22$ & 16 & $\mathrm{AB}$ & $63 \pm 35$ & 9 & B \\
\hline $\mathrm{Rb}$ & $71 \pm 73$ & 12 & A & $36 \pm 30$ & 7 & B & $23 \pm 25$ & 3.2 & B \\
\hline $\mathrm{Cu}$ & $442 \pm 653$ & 84 & B & $401 \pm 371$ & 81 & B & $153 \pm 238$ & 19 & $\mathrm{~A}$ \\
\hline As & $310 \pm 270$ & 77 & $\mathrm{~A}$ & $132 \pm 145$ & 33 & B & $107 \pm 32$ & 32 & $\mathrm{~B}$ \\
\hline $\mathrm{Pb}$ & $169 \pm 286$ & 28 & $\mathrm{~A}$ & $43 \pm 46$ & 10 & B & $27 \pm 32$ & 4 & $\mathrm{~B}$ \\
\hline $\mathrm{Ba}$ & $46 \pm 52$ & 16 & $\mathrm{~A}$ & $186 \pm 144$ & 43 & $\mathrm{~B}$ & $64 \pm 79$ & 11 & $\mathrm{~A}$ \\
\hline $\mathrm{Zn}$ & $729 \pm 1063$ & 255 & $\mathrm{~A}$ & $831 \pm 445$ & 153 & A & $1621 \pm 776$ & 77 & B \\
\hline
\end{tabular}


Table 8. Standardised canonical coefficients from hatchling Octopus pallidus spatial data for discriminant functions (DF) 1 and 2 for each element entered in the final step-wise discriminant function analysis. Coefficients represent the relative contribution of each element to each DF

\begin{tabular}{|lrr|}
\hline Element & DF1 & DF2 \\
\hline $\mathrm{Pb}$ & 0.74 & 0.58 \\
$\mathrm{Ba}$ & 1.04 & 0.27 \\
$\mathrm{Rb}$ & -1.81 & 0.74 \\
$\mathrm{Mg}$ & 1.35 & 0.18 \\
$\mathrm{Cu}$ & 1.21 & 0.85 \\
$\mathrm{As}$ & -0.72 & -1.84 \\
$\mathrm{Li}$ & -0.47 & 0.53 \\
\hline
\end{tabular}

respectively (Fig. 4). However, both $\mathrm{MP}$ and $\mathrm{CH}$, for which only small sample sizes were available, showed considerable within-site variation. There was some similarity between $\mathrm{CH}$ and NWB elemental signatures, which is reflected in the incorrect assignment of $3 \mathrm{CH}$ individuals $(6.7 \%)$ to NWB. However, overall classification success was high (84\%) (Table 9).

\section{Temporal variation of hatchling signatures}

Temporal variation in multi-element hatchling signatures from NWB were highly significant (MANOVA, Pillai's trace $=1.28, F_{14,104}=13.16, \mathrm{p}<0.001$ ). However, $\mathrm{Sr}, \mathrm{Mn}, \mathrm{Rb}, \mathrm{Pb}$ and As did not significantly contribute to temporal differences; differences could largely be attributed to $\mathrm{Mg}$ and Zn (Fig. 5). Discriminant functions 1 and 2 described 84 and $16 \%$ of the variation, respectively. Individuals from Collection 3 at NWB had the most distinct signature, while those from Collections 1 and 2 shared some overlap. The second canonical plot of the hatchling spatial data showed that the degree of separation between the 3 sites was little changed by the addition of the NWB individuals from Collections 2 and 3. Furthermore, using the pooled NWB samples, the classification success of the hatchlings was only marginally lower, with only 1 extra indi-

Table 9. Predicted group memberships from cross-validation classification procedures for each site, based on discriminant function analysis scores from hatchling Octopus pallidus spatial data. Results are given as percentage of the total number traced back to each site; bold values highlight correct classifications. For site abbreviations, see Table 1

\begin{tabular}{|lccc|}
\hline Site & NWB & MP & CH \\
\hline NWB & $\mathbf{9 6 . 4}$ & 0 & 3.6 \\
MP & 16.7 & $\mathbf{8 3 . 3}$ & 0 \\
CH & 20.0 & 6.7 & $\mathbf{7 3 . 3}$ \\
\hline
\end{tabular}

vidual from $\mathrm{CH}$ incorrectly assigned to NWB. Ageing results showed that the adults from $\mathrm{CH}(\mathrm{n}=28)$ had a mean age of $262 \mathrm{~d}(8.7 \mathrm{mo}$ ) ( $\mathrm{SE} \pm 13.1$ ) (Fig. 6). This is close to the desired age-cohort of the adults, which were collected $234 \mathrm{~d}(7.8 \mathrm{mo})$ after the hatchlings (i.e. adults would have hatched at a similar time to the hatchlings analysed for the hatchling signatures). Although the majority were $\leq 6$ mo old, a third of the animals were over 10 mo old.

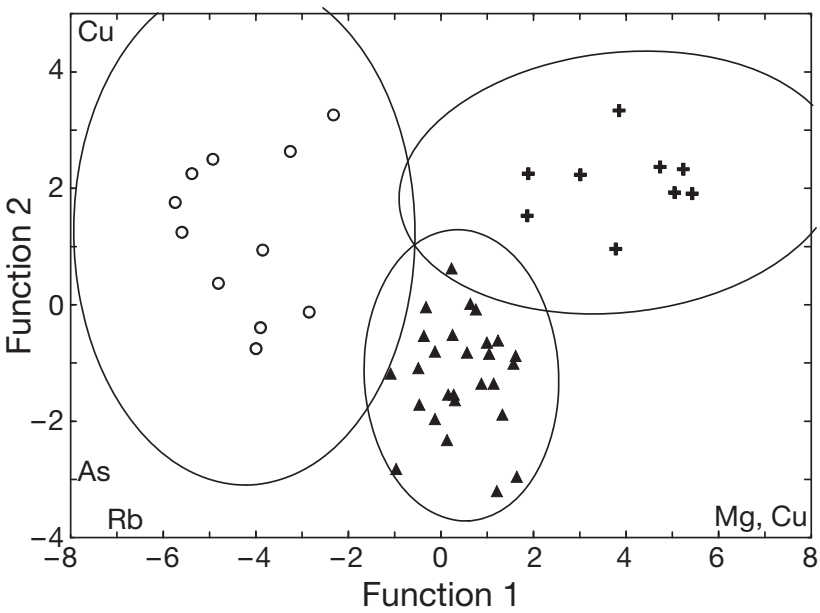

Fig. 4. Canonical discriminant plots comparing multi-element signatures of hatchlings Octopus pallidus among sites. Elements that contributed most variation to the data (canonical coefficients) are indicated at both ends of each axis. Ellipses represent $95 \%$ confidence intervals around the centroids of each group. «: Northwest Bay; O: Circular Head; +: Mercury Passage

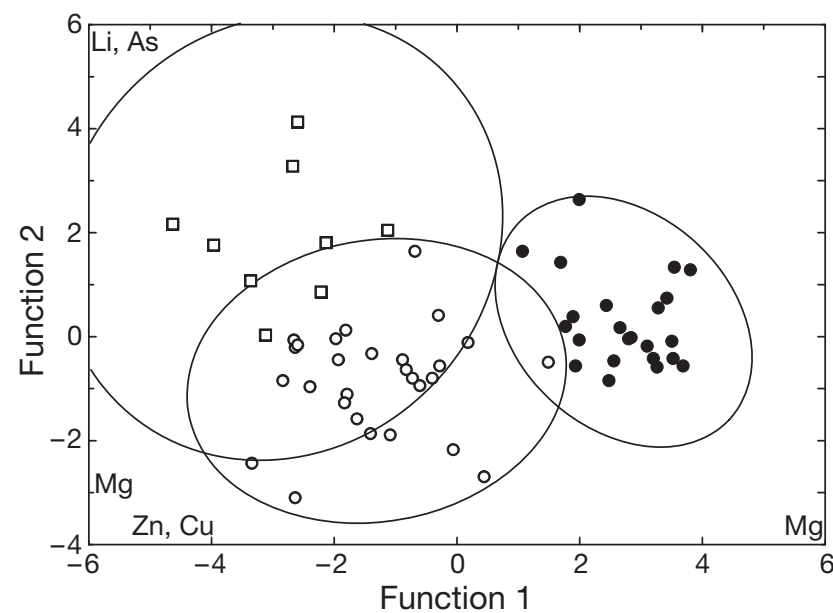

Fig. 5. Canonical discriminant plots comparing multi-element signatures of Octopus pallidus hatchlings collected at Northwest Bay (NWB) at 3 different times. Elements that contributed most variation to the data (canonical coefficients) are indicated at both ends of each axis. Ellipses represent $95 \%$ confidence intervals around the centroids of each group. o: NWB 1; 口: NWB 2; •: NWB 3 


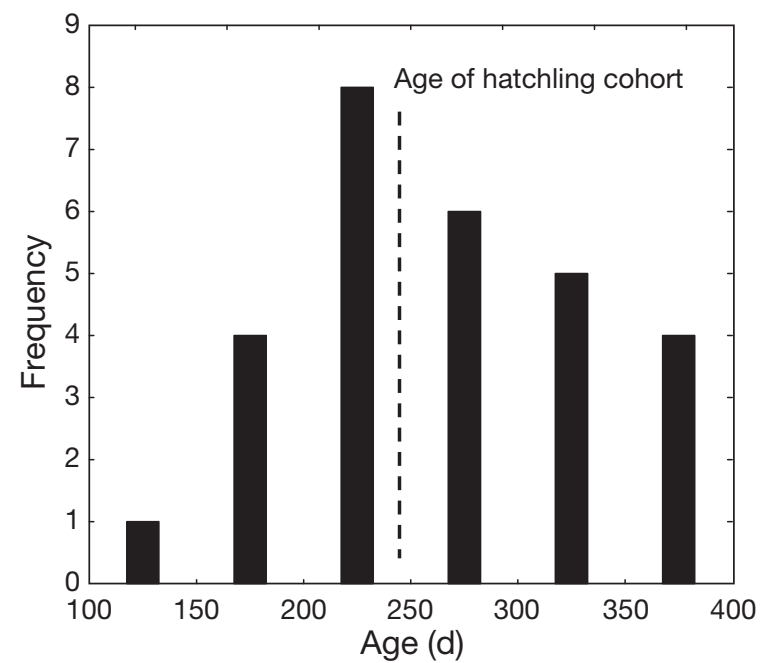

Fig 6. Octopus pallidus. Age distribution of individuals $(\mathrm{n}=$ 28) collected from Circular Head $(\mathrm{CH}),---$ : theoretical age of the hatchling cohort at the time adults were collected (7.8 mo later)

\section{DISCUSSION}

The multi-elemental signatures of the 5 adult groups suggest that, in Tasmania, Octopus pallidus has a highly structured population, and the vast majority of individuals within each group appeared to share a common origin. Although there was some differentiation between the 2 sites closest to each other, WFI and EFI, which are approximately $85 \mathrm{~km}$ apart, it is possible that the localised spatial range of each subpopulation is substantially smaller. Based on the consistency of our results, and considering the holobenthic life history strategy of $O$. pallidus, it is likely that the natal origins of each sub-population are proximate to the respective collection sites. The very high levels of $\mathrm{Pb}$ found in all NWB signatures is also suggestive of such dispersal patterns. NWB is likely to have higher $\mathrm{Pb}$ levels than the other sites due to its proximity to the Derwent estuary, a relatively polluted water body with significantly elevated levels of $\mathrm{Pb}$ (Jones et al. 2003). The population structure of $O$. pallidus, therefore, reflects an expected congruence between early life history strategy and level of dispersal from the parental population. In contrast, an elemental analysis study of an Octopus maorum population (a merobenthic species with planktonic hatchlings) indicated some structure, but also a degree of connectivity (Doubleday et al. 2008). There are no published studies which have utilised elemental signatures to investigate populations of holobenthic cephalopods. However, using genetic markers, high levels of structure have also been identified in 2 species of holobenthic cuttlefish, with populations showing subdivision on a scale of only $300 \mathrm{~km}$ (Perez-Losada et al. 2002, Kassahn et al. 2003). Little is known about the post-hatchling behaviour of cephalopods; however, it has been suggested that horizontal dispersal distance may be as small as $1 \mathrm{~km}$ in small holobenthic cephalopods (Boletzky 2003).

The structure of the Octopus pallidus population has important implications for its commercial fishery, which includes the areas of $\mathrm{CH}, \mathrm{EFI}$ and WFI. Due to limited replenishment from neighbouring sources and limited dispersal from their natal habitats, these apparently localised sub-stocks may be vulnerable to rapid depletion from fishing and natural environmental change. Disregarding stock complexity in fisheries management may cause a reduction in productivity, stock abundance, genetic diversity, and a species' adaptive potential (Stephenson 1999, Hauser et al. 2002). Furthermore, models have predicted that biological parameters obtained from several aggregated sub-stocks and applied to a single population management approach are likely to be inaccurate and nonconservative (Frank \& Brickman 2000). Additional repeat sampling on smaller spatial scales will be needed to define the maximum size of the $O$. pallidus sub-stocks within the region, and a further genetic study would elucidate whether such population subdivisions occur on an inter-generational time scale. However, based on the results of this study, the stocks at $\mathrm{CH}$, EFI and WFI should be considered as discrete management units to maintain population complexity.

Hatchling signatures could not be used to trace adults back to their natal site due to significant differences between hatchling and adult signatures. Element concentrations in the hatchling stylets were orders of magnitude higher than those in the adult stylets, suggesting that the level of $\mathrm{Ca}$ (the internal standard) may be less than $13 \%$ in the hatchling stylets. Raw data from the laser ablation analysis indicate that hatchling stylets contained $\mathrm{Ca}$; however, it is plausible that their soft, pliable and transparent structure (in comparison to the tough opaque adult structure) is not fully calcified at hatching. Several studies have successfully used juvenile elemental signatures, obtained from $\mathrm{CaCO}_{3}$-based structures, to trace adults back to their site of origin (e.g. Hamer et al. 2005, Becker et al. 2007, Feyrer et al. 2007). However, stylets are not composed of $\mathrm{CaCO}_{3}$, but are thought to be largely organic (see Doubleday et al. 2007 for more details). It is important, therefore, that the process of stylet formation is examined further and that the concentration of $\mathrm{Ca}$ in hatchling and juvenile stylets is quantified. If stylets became completely calcified soon after hatching, 'near hatching' eggs should be reared in a closed aquarium system (containing water from the sample site) for 1 to $2 \mathrm{wk}$ prior to dissection. Although this may slightly alter the water chemistry, confounding effects may be marginal as embryos 
would still have developed in situ for 3 to 4 mo. Obtaining larger stylets from older hatchlings would also greatly improve laser ablation success. Hatchling signatures had lower discriminating power compared to the adults, due to higher detection limits (smaller spot size) and lower analytical precision (lower ablation yield). Furthermore, the small sample sizes, particularly from MP, were wholly due to many stylets being too small to discern from the surrounding tissue. If the above approaches could be implemented, targeted elemental analysis could be an effective technique for the determination of juvenile and adult connectivity, natal origins, and important source populations.

Regardless of the problems associated with the hatchling analyses, the adult data should still be valid. Calcium concentration within the inner regions of the adult stylet has been found to be consistent (at 13\%) between individuals (Doubleday et al. 2007). In addition, the near $100 \%$ success in the present study of tracing adults back to their collection site also suggests that Ca concentrations were stable. Accurate absolute values are of relatively low importance due to the lack of matrix-matched standards, although relative comparisons in signatures can be made if analytical precision is good (see Becker et al. 2005, Zumholz et al. 2007). A key assumption of targeted elemental studies to provide an accurate measure of the environmental history of an individual is that the structure does not undergo post-depositional modification (Campana 1999). The lack of a relationship between element concentrations and age in the present study suggests that elements do not undergo further modification (calcification) between at least 4 and 12 mo of age. Until it is determined that there is no such relationship between elemental concentrations and age at the age of 1 to $4 \mathrm{mo}$, it is possible to argue that the signature from the pre-hatch region could represent the first 4 mo of an individual's life. However, if this was the case, it would still seem unlikely that individuals hatched elsewhere and then dispersed as adults to their respective collection sites.

The successful site separation and classification of hatchlings in the present study indicates that Ca concentration was relatively consistent between stylets, and thus relative comparisons between signatures can still be made. The assessment of short-term stability of hatchling signatures indicates that there was a level of temporal variation within a time frame of 3.5 mo; however, the results further indicated that spatial variation largely outweighed temporal variation. The age data from $\mathrm{CH}$ show that, although many individuals were of the correct age (ie. matched the hatchling cohort), some were over 10 mo old. As temporal variation was shown to have minimal effect on signatures within a 3 mo period; however, the majority of adults assessed in the present study were within the correct age range to be traced back to their natal origins. Since Octopus pallidus can reach an age of 18 mo (Leporati et al. 2008), it would be important to either assess the level of temporal variation and its influence on spatial variation over at least an 8 mo time scale, or to select individuals which are of the correct age.

\section{CONCLUSIONS}

The present study demonstrates that Octopus pallidus has a highly structured population, which reflects the species' early life history strategy. The results from the adult analyses further support that targeted elemental analysis is an effective method for examining the population structure of octopuses. Temporal variation in elemental signatures should be considered and assessed in future studies to ensure that they do not confound spatial analyses, particularly if hatchling signatures will be used to classify adults back to their natal origins. The results from the hatchling signatures indicate that they can be used to discriminate between sites; however, due to the possibly lower Ca levels and very small size of hatchling stylets, they are currently limited in their potential as tags for natal origin. However, improvements to the methods, such as rearing of hatchlings for several weeks in aquaria prior to dissection, may rectify these initial problems. This is the first known study to use stylet elemental signatures to examine the population structure of a holobenthic octopus species, and as such will not only have important implications for the commercial O. pallidus fishery, but also for other commercial octopus species around the world.

Acknowledgements. We thank the Hardy family (TOP Fish) for providing us with dissecting facilities and samples from northern Tasmania, Spring Bay Seafoods for deploying and retrieving octopus pots in their lease site, TAFI MRL staff and students for assistance in the collection of both adults and hatchlings, S. Leporati for providing raw age data for the $\mathrm{CH}$ individuals, and S. Gilbert (CODES) for her technical assistance with LA ICPMS. The project was funded by the Department of Primary Industries \& Water (Tasmania), a Winifred Violet Scott Estate grant and a Holsworth Wildlife Research Endowment.

\section{LITERATURE CITED}

Arkhipkin AI, Campana SE, Fitzgerald J, Thorrold SR (2004) Spatial and temporal variation in elemental signatures of statoliths from the Patagonian longfin squid (Loligo gahi). Can J Fish Aquat Sci 61:1212-1224

Arreguín-Sánchez F, Solís-Ramirez MJS, González de la Rosa ME (2000) Population dynamics and stock assessment for Octopus maya (Cephalopoda: Octopodidae) fishery in the Campeche Bank, Gulf of Mexico. Rev Biol Trop 48: 323-331 
Becker BJ, Fodrie FJ, McMillan PA, Levin LA (2005) Spatial and temporal variation in trace elemental fingerprints of mytilid mussel shells: a precursor to invertebrate larval tracking. Limnol Oceanogr 50:48-61

Becker BJ, Levin LA, Fodrie FJ, McMillan PA (2007) Complex larval connectivity patterns among marine invertebrate populations. Proc Natl Acad Sci USA 104: 3267-3272

Bizikov VA (2004) The shell in Vampyropoda (Cephalopoda): morphology, functional role and evolution. Ruthenica 3: $1-88$

Boletzky Sv (2003) Biology of early life stages in cephalopod molluscs. Adv Mar Biol 44:143-203

Bradbury IR, Campana SE, Bentzen P (2008) Estimating contemporary early life-history dispersal in an estuarine fish: integrating molecular and otolith elemental approaches. Mol Ecol 17:1438-1450

Buresch KC, Gerlach G, Hanlon RT (2006) Multiple genetic stocks of longfin squid Loligo pealeii in the NW Atlantic: stocks segregate inshore in summer, but aggregate offshore in winter. Mar Ecol Prog Ser 310:263-270

- Campana SE (1999) Chemistry and composition of fish otoliths: pathways, mechanisms and applications. Mar Ecol Prog Ser 188:263-297

Campana SE, Thorrold SR (2001) Otoliths, increments, and elements: keys to a comprehensive understanding of fish populations? Can J Fish Aquat Sci 58:30-38

Carvalho GR, Hauser L (1994) Molecular genetics and the stock concept in fisheries. Rev Fish Biol Fish 4:326-350

Doubleday ZA, Semmens JM, Pecl GT, Jackson GD (2006) Assessing the validity of stylets as ageing tools in Octopus pallidus. J Exp Mar Biol Ecol 338:35-42

$>$ Doubleday ZA, Belton D, Pecl GT, Semmens JM (2007) Quantitative elemental imaging of octopus stylets using PIXE and the nuclear microprobe. Nucl Instr Meth Phys Res B: Beam Interac Mat Atoms 266:67-72

> Doubleday ZA, Pecl GT, Semmens JM, Danyushevsky L (2008) Using stylet elemental signatures to determine the population structure of Octopus maorum. Mar Ecol Prog Ser 360:125-133

Farnham IM, Singh AK, Stetzenbach KJ, Johannesson KH (2002) Treatment of nondetects in multivariate analysis of groundwater geochemistry data. Chemometr Intell Lab 60:265-281

Feyrer F, Hobbs J, Baerwald M, Sommer T and others (2007) Otolith microchemistry provides information complementary to microsatellite DNA for a migratory fish. Trans Am Fish Soc 136:469-476

Forrester GE, Swearer SE (2002) Trace elements in otoliths indicate the use of open-coast verses bay nursery habitats by juvenile California halibut. Mar Ecol Prog Ser 241: 201-213

Fowler SW, Gillanders BM, Hall KC (2005) Relationships between elemental concentration and age from otoliths of adult snapper (Pagrus auratus, Sparidae). Mar Freshw Res 56:661-676

Frank KT, Brickman D (2000) Allee effects and compensatory population dynamics within a stock complex. Can J Fish Aquat Sci 57:513-517

Gillanders BM (2002) Connectivity between juvenile and adult fish populations: do adults remain near their recruitment estuaries? Mar Ecol Prog Ser 240:215-223

Gillanders BM (2005) Using elemental chemistry of fish otoliths to determine connectivity between estuarine and coastal habitats. Estuar Coast Shelf Sci 64:47-57

Hamer PA, Jenkins GP, Gillanders BM (2005) Chemical tags in otoliths indicate the importance of local and distant settlement areas to populations of a temperate sparid,
Pagrus auratus. Can J Fish Aquat Sci 62:623-630

Hauser L, Adcock GJ, Smith PJ, Bernal Ramirez JH, Carvalho GR (2002) Loss of microsatellite diversity and low effective population size in an overexploited population of New Zealand snapper (Pagrus auratus). Proc Natl Acad Sci USA 99:11742-11747

Jackson GD (1994) Application and future potential of statolith increment analysis in squids and sepioids. Can J Fish Aquat Sci 51:2612-2625

Jones BG, Chenhall BE, Debretsion F, Hutton AC (2003) Geochemical comparisons between estuaries with nonindustrialised and industrialised catchments: the Huon and Derwent River estuaries, Tasmania. Aust J Earth Sci 50:653-667

Jones GP, Planes S, Thorrold SR (2005) Coral reef fish larvae settle close to home. Curr Biol 15:1314-1318

> Kassahn KS, Donnellan S, Fowler SW, Hall KC, Adams M, Shaw PW (2003) Molecular and morphological analyses of the cuttlefish Sepia apama indicate a complex population structure. Mar Biol 143:947-962

> Leporati SC, Semmens JM, Pecl GT (2008) Determining the age and growth of wild octopus using stylet increment analysis. Mar Ecol Prog Ser 367:213-222

Maltagliati F, Belcari P, Casu D, Casu M, Sator P, Vargiu G, Castelli A (2002) Allozyme genetic variability and gene flow in Octopus vulgaris (Cephalopoda, Octopodidae) from the Mediterranean Sea. Bull Mar Sci 71:437-486

Oosthuizen A, Jiwaji M, Shaw P (2004) Genetic analysis of the Octopus vulgaris population on the coast of South Africa. S Afr J Sci 100:603-607

Orsi Relini L, Mannini A, Fiorentino F, Palandri G, Relini G (2006) Biology and fishery of Eledone cirrhosa in the Ligurian Sea. Fish Res 78:72-88

Perez-Losada M, Guerra A, Carvalho GR, Sanjuan A, Shaw PW (2002) Extensive population subdivision of the cuttlefish Sepia officinalis (Mollusca: Cephalopoda) around the Iberian Peninsula indicated by microsatellite DNA variation. Heredity 89:417-424

- Semmens JM, Pecl GT, Gillanders BM, Waluda CM and others (2007) Approaches to resolving cephalopod movement and migration patterns. Rev Fish Biol Fish 17:401-423

Shaw PW, Pierce GJ, Boyle PR (1999) Subtle population structuring within a highly vagile marine invertebrate, the veined squid Loligo forbesi, demonstrated with microsatellite DNA markers. Mol Ecol 8:407-417

Stephenson RL (1999) Stock complexity in fisheries management: a perspective of emerging issues related to population sub-units. Fish Res 43:247-249

Stranks TN (1996) Biogeography of Octopus species (Cephalopoda: Octopodidae) from southeastern Australia. Am Malacol Bull 12:145-151

Thorrold SR, Latkoczy C, Swart PK, Jones CS (2001) Natal homing in a marine fish metapopulation. Science 291: 297-299

Warner RR, Swearer SE, Caselle JE, Sheehy M, Paradis G (2005) Natal trace-elemental signatures in the otoliths of an open-coast fish. Limnol Oceanogr 50:1529-1542

Zacherl DC (2005) Spatial and temporal variation in statolith and protoconch trace elements as natural tags to track larval dispersal. Mar Ecol Prog Ser 290:145-163

Ziegler PE, Lyle JM, Pecl GT, Moltschaniwskj NA, Haddon M (2007) Tasmanian scalefish fishery 2006. Tasmanian Aquaculture and Fisheries Institute, Hobart

> Zumholz K, Klügel A, Hansteen T, Piatkowski U (2007) Statolith microchemistry traces the environmental history of the boreoatlantic armhook squid Gonatus fabricii. Mar Ecol Prog Ser 333:195-204 